\title{
Conservation agriculture improves yield and reduces weeding activity in sandy soils of Cambodia
}

\author{
Don A. Edralin ${ }^{1} \cdot$ Gilbert C. Sigua $^{2} \cdot$ Manuel R. Reyes $^{3} \cdot$ Michael J. Mulvaney $^{4}$ • \\ Susan S. Andrews ${ }^{5}$
}

Accepted: 22 September 2017 /Published online: 12 October 2017

(C) INRA and Springer-Verlag France SAS 2017

\begin{abstract}
The years of intensive tillage in Cambodia have caused significant decline in agriculture's natural resources that could threaten its future of agricultural production and sustainability. Conventional tillage could cause rapid loss of soil organic matter, leading to a high potential for soil degradation and decline of environmental quality. Hence, a better and comprehensive process-based understanding of differential effects of tillage systems and crop management on crop yield is critically needed. A study was conducted in 10 farmer's fields to evaluate the effect of conservation agriculture and conventional tillage on yield of selected crops and weeding activity in two villages of Siem Reap, Cambodia. The experiment was laid out following a $2 \times 2$ factorial treatment combination in randomized complete block design. Each treatment was replicated five times. Each farmer's field was divided into four plots and was randomly assigned with production management and irrigation treatments, respectively. We demonstrated that our results supported the overall premises of conservation agriculture. Average yields of selected crops were significantly $(\leq 0.001)$ improved in plots with
\end{abstract}

Gilbert C. Sigua

gilbert.sigua@ars.usda.gov

1 North Carolina Agricultural and Technical State University, Greensboro, NC, USA

2 USDA-ARS, Coastal Plains Soils, Water and Plant Research Center, Florence, SC, USA

3 Feed the Future Innovation Lab for Collaborative Research on Sustainable Intensification, Kansas State University, Manhattan, KS, USA

4 West Florida Research and Education Center, University of Florida, Milton, FL, USA

5 USDA, Natural Resource Conservation Service, Lincoln, NE, USA conservation agriculture $\left(17.1 \pm 6.3\right.$ to $\left.89.3 \pm 40.2 \mathrm{Mg} \mathrm{ha}^{-1}\right)$ compared with conventional tillage $(18.8 \pm 6.4$ to $63.8 \pm 27.7 \mathrm{Mg} \mathrm{ha}^{-1}$ ). Our results showed that manual weeding in all cropping seasons was significantly reduced by about $35 \%$ in conservation agriculture $\left(169 \pm 23\right.$ to $125 \pm 18$ man-day ha $\left.^{-1}\right)$, which can be attributed to existing cover crops and surface mulch. Overall, our results suggest that in smallholder commercial household farms, adoption of conservation agriculture had a profitable production management system, which could save natural resources, improve yield, and reduce labor. We proved for the first time that in Cambodian smallholder commercial household farms, adoption of conservation agriculture saves natural resources, improves yield, and reduces labor. Additional studies are encouraged to further test the conservation agriculture system for a longer period of time, with repeated cropping sequences.

Keywords Conservation agriculture - Conventional tillage · Drip irrigation · Siem Reap · Cambodia $\cdot$ Weeding $\cdot$ Cover crops $\cdot$ Mulch $\cdot$ Yield

\section{Introduction}

Increasing food production within existing agricultural lands is a continuous challenge for an ever-increasing global population. Success in agricultural production during the Green Revolution can be attributed to several major process components, of which tillage has played a major part. Conventional tillage practices, however, could cause rapid loss of soil organic matter, leading to a high potential for soil degradation and decline for environmental quality in the long run (Lal 2008; Edralin et al. 2016). In order to address global food demands sustainably, striking a balance between food production and environmental impacts is essential. This has been the 
global goal of conservation agriculture (Derpsch 2008; FAO 2011). Figure 1 shows a typical farmer's watering in Cambodia using hand water sprinklers and drip irrigation system for vegetable production under conventional tillage and conservation agriculture management system.

Conservation agriculture is a concept of crop production that aims to achieve high and sustained production levels while conserving the environment (Hobbs, 2007; Derpsch 2008; Kassam et al. 2009; FAO 2011; Edralin et al. 2016). It consists of combining the following principles: (a) soils are not disturbed (by more than $15 \mathrm{~cm}$ in width or more than $25 \%$, whichever is less, of the cropped area) or tilled periodically; (b) more than $30 \%$ of the soil has to be covered with organic residues at planting; and (c) crop rotation has to be implemented involving at least three different crops (FAO 2001; Derpsch 2008; Hobbs et al. 2008; Kassam et al. 2009). Recently, Vanlauwe et al. (2014) suggested including appropriate use of fertilizer as a fourth requirement particularly in smallholder farming conditions in sub-Saharan Africa where fertilizer use is often limited or lacking. Considering the relatively recent proposal for a fourth conservation agriculture component, our study focused on studies defining components, although use of fertilizers is not prohibited in the three-component definition of conservation agriculture.
The applicability and successful adoption of conservation agriculture, however, received mixed review. Giller et al. (2009) has argued that conservation agriculture is inappropriate for resource-constrained smallholder farmers in certain locations at certain times (e.g., with competing resource use of cover crops for animal feed versus mulch and the shift in labor burden to women for weeding). Giller et al. (2009) have further stressed that farming conditions wherein conservation agriculture could meet production goals are yet to be identified. This is particularly true for manual small-scale vegetable production wherein impact of conservation agriculture has not been adequately evaluated.

Yield improvements have been reported on several crops grown under conservation agriculture in several parts of the world. For instance, Thierfelder et al. (2015) found greater corn (Zea mays L.) yields under conservation agriculture over conventional tillage in southern Africa. Yields of maize or other crops have been reported between conservation agriculture and tillage systems not only in African countries but also in North America, Latin America, and Asia (Kassam et al. 2009; Faroooq et al., 2011). Among other things, the main factors attributed to better yields are improved soil physical conditions (i.e., enhanced infiltration and retention of soil moisture) and better fertility status of the soils in the long
Fig. 1 Conventional tilled plots (a) and conservation agriculture (b) with sunn hemp (Crotalaria juncea L.) cover crop under drip irrigation system and/or hand water system in Siem Reap, Cambodia
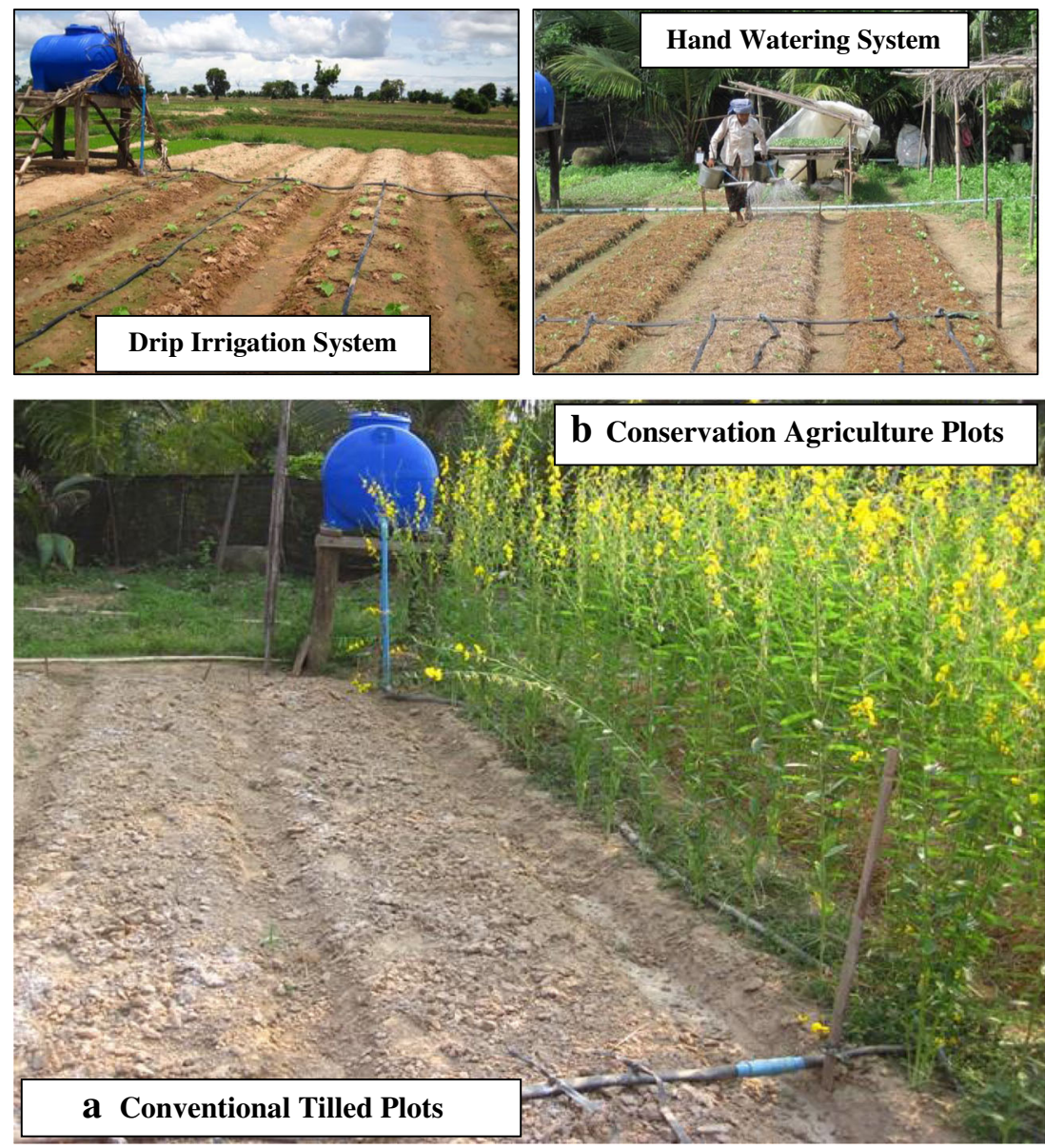
run (Hobbs et al. 2008; Govaerts et al. 2009; Thierfelder et al. 2015). However, cases with similar or even lower crop yields have also been observed with potential underlying factors identified as follows: lack of experience by farmers, slow soil fertility increase, waterlogging during periods of much rainfall on poorly drained soils, delayed crop establishment due to occasional wet and cold soils, fertilizer placement, residue management problems, increased weed competition, residueborne diseases, and soil compaction (Linden et al. 2000; Faroooq et al. 2011; Thierfelder et al. 2015).

Given the quite contrasting findings above, it is apparent that the impacts of conservation agriculture on crop yield are not certain. Such uncertainty lies in regional differences in climate, soil, farming system, farmer knowledge, and availability of resources which can all affect crop performance under conservation agriculture (Giller et al. 2009; Faroooq et al. 2011). While existing literature has focused on impacts of conservation agriculture on agronomic crop yields, effects on vegetable yield have not been sufficiently studied. Responses on vegetable yield under conservation agriculture may also be uncertain if conservation agriculture is implemented without prior testing of its applicability in specific regions of the world.

The years of intensive tillage in many less-developed countries, including Cambodia, have caused significant decline in agriculture's natural resources that could threaten the future of agricultural production and sustainability worldwide (Edralin et al. 2016). Long-term tillage system and site-specific crop management can affect changes in soil properties and processes, so there is a critical need for a better and comprehensive process-level understanding of differential effects of tillage systems and crop management on the direction and magnitude of changes in crop yield, soil carbon storage, and other soil properties. A study was conducted in 10 farmer's fields to evaluate the effect of conservation agriculture and conventional tillage on yield of selected crops and weeding activity in two villages of Siem Reap, Cambodia (Fig. 1). Additionally, our paper was aimed to address the research gap involving applicability of conservation agriculture in countries of Southeast Asia with vegetable production that are non-

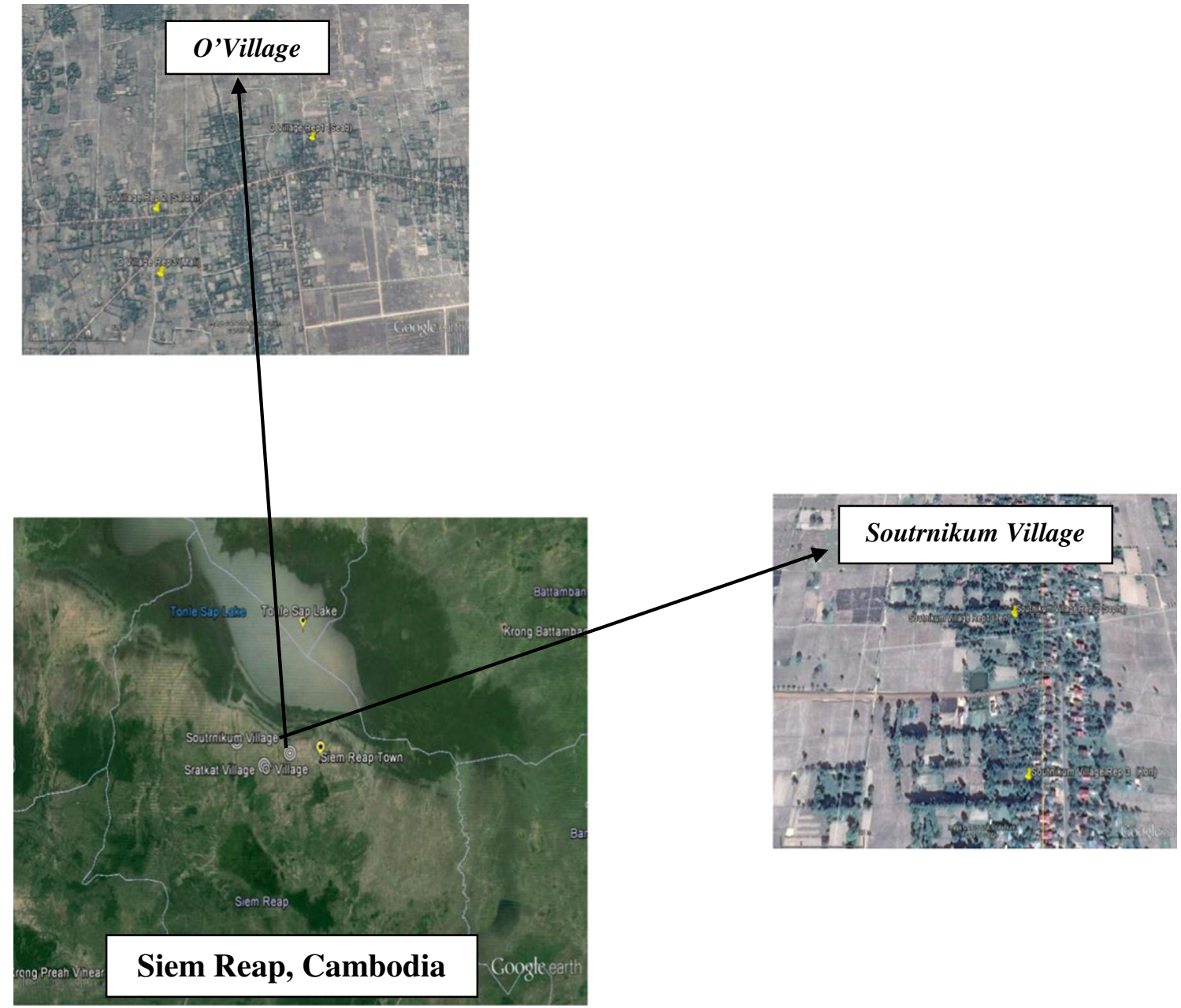

Fig. 2 Geographical location of the study sites showing the two villages in Siem Reap, Cambodia. (Siem Reap, Cambodia: $13^{\circ} 20^{\prime} 58.38^{\prime \prime} \mathrm{N}$, $104^{\circ} 2^{\prime} 49.75^{\prime \prime}$ E; O' Village, Siem Reap, Cambodia: $13^{\circ} 19^{\prime} 31.50^{\prime \prime} \mathrm{N}$, $103^{\circ} 57^{\prime} 24.22^{\prime \prime}$ E; Soutrnikum, Siem Reap, Cambodia: $13^{\circ} 16^{\prime} 48.73^{\prime \prime} \mathrm{N}$, $104^{\circ} 7^{\prime}$ 47.77" E; Source: Google Earth, 2015) 
herbicide dependent and are manually irrigated sandy soil similar to the two study sites in Cambodia.

\section{Materials and methods}

\subsection{Site description and site preparation}

The geographic location of the study sites is shown in Fig. 2. Briefly, the 10 study sites were located in two villages in Siem Reap Cambodia: O'Village (13 ${ }^{\circ} 19^{\prime} 31.50^{\prime \prime} \mathrm{N}$, $\left.103^{\circ} 57^{\prime} 24.22^{\prime \prime} \mathrm{E}\right)$; and Soutrikum Village (13 $13^{\circ} 16^{\prime} 48.73^{\prime \prime} \mathrm{N}$, $\left.104^{\circ} 7^{\prime} 47.77^{\prime \prime} \mathrm{E}\right)$. The major soil types in the villages were similar to that of the Arenosols, prey Khmer Soil Group, and FAO soil classification, as described by Seng et al. (2005), equivalent to Soil Order Entisol and Suborder Psamments according to the USDA soil classification (Soil Quality Institute Staff 1998). The soil properties include having a low organic carbon $\left(0.5 \mathrm{~g} \mathrm{~kg}^{-1}\right)$; low total organic $\mathrm{N}\left(0.5 \mathrm{~g} \mathrm{~kg}^{-1}\right)$ with $73 \%$ sand, $22 \%$ silt, and $5 \%$ clay; low CEC; exchangeable K; and Olsen $\mathrm{P}$ with high hydraulic conductivity (Seng et al. 2005). Additionally, other soil properties are included in Table 1.

Cambodia has two distinct seasons, marked with dry and wet conditions. Averaged over 100 years, Cambodia has an annual rainfall of $1837 \mathrm{~mm}$ and annual mean temperature of $26.5^{\circ} \mathrm{C}$ (World Bank Group 2015). A critical period of crop production was identified which falls on the months of April to July, referred to as the early wet season, due to erratic rainfall patterns (Seng et al. 2005) with high temperature (Fig. 3).

In conventional tillage, the soil was continuously tilled at about 20-cm depth, using hoe and moldboard plow drafted by two buffalos during the early wet season of 2013, wet to dry season in 2013, and dry season in 2013 and 2014. The soils were then evened out using rakes, beds were remade, remaining residues were taken out and sometimes burned, and holes were manually dug for the next crop. In conservation agriculture,

Table 1 Selected properties of soils in the study sites, planting season, selected crops, method of planting, and fertilizer application rate by crops in O'Village and Soutrikum Village in Siem Reap, Cambodia

\begin{tabular}{llll}
\hline Soil properties & Number & O'Village Village & Soutrikum Village \\
$\mathrm{pH}$ & 36 & $5.15 \pm 0.45$ & $6.31 \pm 0.64$ \\
$\mathrm{EC}\left(u \mathrm{~S} \mathrm{~cm}^{-1}\right)$ & 36 & $80.0 \pm 30.0$ & $306.0 \pm 136.0$ \\
$\begin{array}{l}\text { Soil organic carbon }(\mathrm{g} \\
\quad 36\end{array}$ & & $8.8 \pm 2.5$ & $8.3 \pm 2.2$ \\
$\left.\quad \mathrm{~kg}^{-1}\right)$ & & \\
Total nitrogen $\left(\mathrm{g} \mathrm{kg}^{-1}\right)$ & 36 & $0.58 \pm 0.15$ & $0.70 \pm 0.14$ \\
Potassium $\left(\mathrm{mg} \mathrm{kg}^{-1}\right)$ & 36 & $72.4 \pm 43.2$ & $125.2 \pm 41.1$ \\
Phosphorus $\left(\mathrm{m} \mathrm{kg}^{-1}\right)$ & 36 & $69.7 \pm 21.5$ & $76.4 \pm 30.7$ \\
Bulk density $\left(\mathrm{g} \mathrm{cm}^{-3}\right)$ & 36 & $1.44 \pm 0.11$ & $1.42 \pm 0.07$ \\
\hline
\end{tabular}

Planting season

Crop selection by village

Early wet season 2013

Wet to dry season 2013

Dry season 2013-2014

Early wet season 2014

Wet season 2013

Wet to dry season 2013

Early wet to wet season 2014

Wet season 2014
O’Village, Prasat Bakong District

Cucumber (Cucumis sativus L).

Tomato (Solanum lycopersicum L.)

Yard-long bean (Vigna unguiculata L. subsp. Sesquipedalis)

Round eggplant (Solanum melongena $\mathrm{L}$.)

Soutrikum Village Trabek District

Chinese kale (Brassica oleracea L. var. Alboglabra)

Cabbage (Brassica oleracea L. var. Capitata)

Tomato (Solanum lycopersicum L.)

Yard-long bean (Vigna unguiculata L. subsp. sesquipedalis)

\begin{tabular}{|c|c|c|c|c|c|}
\hline Crop/vegetable & $\begin{array}{l}\text { Method of planting } \\
\text { crop }\end{array}$ & $\begin{array}{l}\text { Planting } \\
\text { distance }\end{array}$ & $\begin{array}{l}\text { Rows per vegetable } \\
\text { bed }^{\text {a }}\end{array}$ & $\begin{array}{l}\text { Total nutrients }{ }^{\mathrm{b}} \text { applied } \\
\mathrm{N}-\mathrm{P}_{2} \mathrm{O}_{5}-\mathrm{K}_{2} 0 \mathrm{~kg} \mathrm{ha}^{-1}\end{array}$ & $\begin{array}{l}\text { Method of } \\
\text { application }\end{array}$ \\
\hline Cabbage & Transplant & $0.3 \times 0.3 \mathrm{~m}$ & 2 & $113-72-58$ & 1 basal +3 split \\
\hline Cauliflower & Transplant & $0.3 \times 0.3 \mathrm{~m}$ & 2 & $98-46-34$ & 1 basal +3 split \\
\hline Chinese kale & Transplant & $0.15 \times 0.15 \mathrm{~m}$ & 3 & $98-46-34$ & 1 basal +3 split \\
\hline Cucumber & Transplant & $0.5 \times 0.5 \mathrm{~m}$ & 2 & $113-72-58$ & 1 basal +6 split \\
\hline Eggplant & Transplant & $0.5 \times 0.5 \mathrm{~m}$ & 2 & $90-105-51$ & 1 basal +6 split \\
\hline Tomato & Transplant & $0.5 \times 0.5 \mathrm{~m}$ & 2 & $90-105-51$ & 1 basal +6 split \\
\hline Yard-long bean & Direct sowing & $0.4 \times 0.4 \mathrm{~m}$ & 2 & $111-135-78$ & 1 basal +6 split \\
\hline
\end{tabular}

${ }^{\text {a }}$ Bed size $1 \times 10 \mathrm{~m}$

${ }^{\mathrm{b}}$ Resulting fertilizer used per crop based on applied inorganic fertilizers 
Fig. 3 Hundred-year monthly average of temperature and rainfall in study sites located in Siem Reap, Cambodia

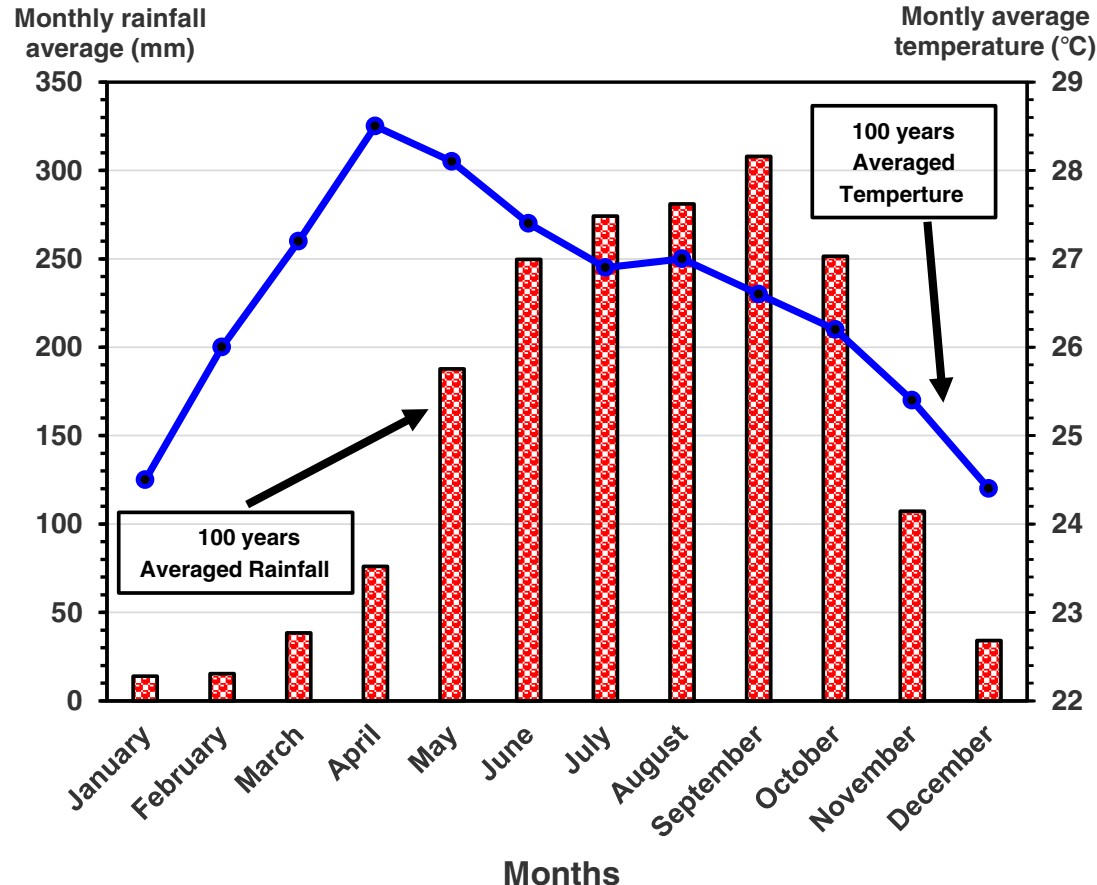

tillage was no longer repeated after the first crop production, and dry rice straws (Oryza sativa L.) of about $15 \mathrm{Mg} \mathrm{ha}^{-1}$ was placed on top of the vegetable beds' surface as mulch $(8-\mathrm{cm}$ height). Rice is the main crop for many lowland areas in Cambodia. In most areas of Siem Reap, Cambodia, rice has been grown as monoculture for a long time. Farmers spread rice straws in the field so as to conserve soil moisture, prevent weed growth, and reduce soil erosion. This practice of using crop residues as mulch contributes towards maintenance of soil fertility over a longer of time. In Cambodia, there were about 2,346,889 ha of paddy rice fields for the years 2005-2006 (FAO 2006). Rice straw is either removed from the field, incorporated in the soil, or used as much for the following crop. Overall, having this rice straw available in the field following rice cultivation, vegetation production will be benefited the most. Since mulching is needed in conservation agriculture, the availability of rice straw is indeed beneficial.

Sunn hemp (Crotalaria juncea L.) cover crop was planted at $0.5 \mathrm{~m}$ apart at a rate of $30 \mathrm{~kg} \mathrm{ha}^{-1}$ between rows of crops. One week prior to harvesting the main crop, sunn hemp was then cut from the base of the stem, laid on top of the soil, and covered with rice mulch with the same rate as above. Holes were dug at about $10 \mathrm{~cm}$ in diameter and by $10-12-\mathrm{cm}$ depth for planting the next crop.

\subsection{Experimental design}

The experiment was laid out following a $2 \times 2$ factorial treatment combination in randomized complete block design. Each farmer's field was divided into two main plots where management treatments were randomly assigned. The two main plots were consisted of two production management treatments namely conservation agriculture and conventional tillage. Each treatment was replicated five times. Production management treatment composed of conservation agriculture and conventional tillage was the main plot while the irrigation methods composed of the conventional manual sprinkler-type irrigation and low-cost drip irrigation system were the subplot treatments (Fig. 1). Crop history and/or different crop rotations for the two villages during the study period are presented in Table 1.

\subsection{Production management: conservation agriculture and conventional tillage}

In conservation agriculture, tillage was no longer repeated after the first production, and field dry rice straws (Oryza sativa L.) were placed on top of the vegetable beds' surface as mulch (8$\mathrm{cm}$ height, dry, upon application; $15 \mathrm{Mg} \mathrm{ha}^{-1}$ ). Sunn hemp (Crotalaria juncea L.) cover crop was planted at $0.5 \mathrm{~m}$ apart at a rate of $30 \mathrm{~kg} \mathrm{ha}^{-1}$, in between rows of crops (Fig. 1). The cover crop was cut from the base of the stem, laid on top of the soil, and covered with rice mulch with the same rate as above. Holes were dug at about $10 \mathrm{~cm}$ in diameter and by $10-12-\mathrm{cm}$ depth for planting the next crop. In conventional tillage, the soil was continuously tilled at about 20 -cm depth, using hoe (8 of 10 farmers) and moldboard plow drafted by two buffalos (2 of 10 farmers).

\subsection{Fertilizer and pest management}

Each village, involving 5 farmers, has their own cropping sequence based on market demand (Table 1). As part of pest control measures by farmers, aboveground residues of crops 
belonging to the families of "Solanaceae" and "Fabaceae" in conservation agriculture were removed by cutting from the base of the stem that meets the soil, leaving the roots intact, while in conventional tillage, they were uprooted. Crops belonging to the family of "Brassicas" in conservation agriculture were left on the ground while in conventional tillage, they were uprooted. Aluminum-based (20\%) insecticide with active ingredient "Dinotefuran," brand name "Oshin," was commonly used by farmers and was used as needed and applied on all treatments. Inorganic fertilizers were used, with the same rate applied on all treatments, as basal and side dressed in split applications. The resulting rates of application, based on what has been applied on field per crop, are presented in Table 1. Agricultural lime was uniformly applied on all treatments at the rate of $1 \mathrm{Mg} \mathrm{ha}^{-1}$ before the third production period.

\subsection{Low-cost drip irrigation and conventional manual sprinkler irrigation}

A low-cost drip irrigation system was established in the experiment. This drip irrigation method involved delivery of water through a pipe distribution network consisting of a main pipe, sub-main pipe, manifold and lateral pipes under low pressure, and emission through small outlets of drippers or emitters onto the immediate soil surface close to the plant roots (Ella et al. 2008). The pipes were connected to a 500-L tank, with a hydraulic head of $1 \mathrm{~m}$ (Fig. 1). The drip tapes, labor in installation, and other small items (i.e., gate valves, Teflon tapes, etc.) consisted of $40 \%$ of the total cost of $\$ 127.00$, while the tanks' cost-sharing among farmers was about $60 \%$.

In conventional tilled plots with drip irrigation, the irrigation tapes were laid on top of the ground while in conservation agriculture, they were covered with mulch. Drip irrigation tapes during the dry season were constantly being pulled back because they warp due to solar radiation. In conservation agriculture, the drip irrigation lines remained in place. During establishment of the succeeding crop, scorched drip irrigation tapes were removed from plots with conventional tillage to promote access of land for cultivation. Because of this, replacing the drip irrigation tapes or some connectors has become a usual activity. In conservation agriculture, the drip irrigation tapes were not removed unless the next crop followed a different plant spacing (Table 1).

During the dry season, about $5 \mathrm{~L} \mathrm{~m}^{-2}$ of water was given twice daily, with $2.5 \mathrm{~L} \mathrm{~m}^{-2}$ in the morning and $2.5 \mathrm{~L} \mathrm{~m}^{-2}$ in the afternoon. During the early wet season, $5 \mathrm{~L} \mathrm{~m}^{-2}$ was given every other day depending on rain events. The handdelivered sprinklers also vary between crops and weather conditions; usually for the dry season, 25 trips were done to water $100 \mathrm{~m}^{2}$, carrying 20 -L bucket each trip.

\subsection{Weeding activity}

Hand weeding was initiated on each plot as needed. Each manual weeding activity is being monitored and recorded carefully. The weeding activity is reported in man-day per hectare.

\subsection{Data collection and processing}

In each experimental unit $\left(25 \mathrm{~m}^{2}\right)$, excluding 1 -m borders, vegetables were harvested from a pre-determined and marked area of $9 \mathrm{~m}^{2}$. Vegetables were sorted based on marketable and unmarketable qualities. The actual weight of marketable vegetables from each plot was then extrapolated to a per-hectare basis for data reduction and statistical analysis.

\subsection{Statistical analysis}

The yield of vegetables and weeding time was analyzed using SAS 9.4 (SAS Institute, Cary, NC. USA). The "PROC GLM" was used with each farm as a block. In the model, yield and weeding time were assigned as dependent variable while block, management, irrigation, and the interaction between management and irrigation were assigned as independent variables. The treatment means were separated using Fisher's Protected Least Significant Difference at alpha $\leq 0.10$.

\section{Results and discussion}

\subsection{Yield of selected crops/vegetables}

In O'village, the yield of cucumber during the early wet season of 2013 was not affected by management treatments and irrigation method (Table 2). The average yield of cucumber was $17.9 \mathrm{Mg} \mathrm{ha}^{-1}$ across management treatments. The yield of cucumber (averaged across irrigation method) from plots with conservation agriculture was about $17.1 \pm 6.3 \mathrm{Mg} \mathrm{ha}^{-1}$ compared with the average yield of cucumber $\left(18.8 \pm 6.4 \mathrm{Mg} \mathrm{ha}^{-1}\right)$ from plots with conventional tillage. During the DS 2013, yard-long bean yields were not affected by conservation agriculture or conventional tillage obtaining an average yield of about $25.0 \mathrm{Mg} \mathrm{ha}^{-1}$. On the last cropping season of the experiment, during the EWS 2014, round eggplant yield was significantly greater by about $2.0 \mathrm{Mg} \mathrm{ha}^{-1}$ in conservation agriculture compared with conventional tillage (Table 2). Overall, the yield of cucumber, yard-long bean and round eggplant, was not affected by irrigation method. Conservation agriculture plots with drip system have the greatest yield of round eggplant $\left(24.7 \pm 7.0 \mathrm{Mg} \mathrm{ha}^{-1}\right)$ while the lowest yield of round eggplant $\left(21.6 \pm 5.8 \mathrm{Mg} \mathrm{ha}^{-1}\right)$ was obtained from plots with conventional tillage + hand sprinkler system (Table 2). 


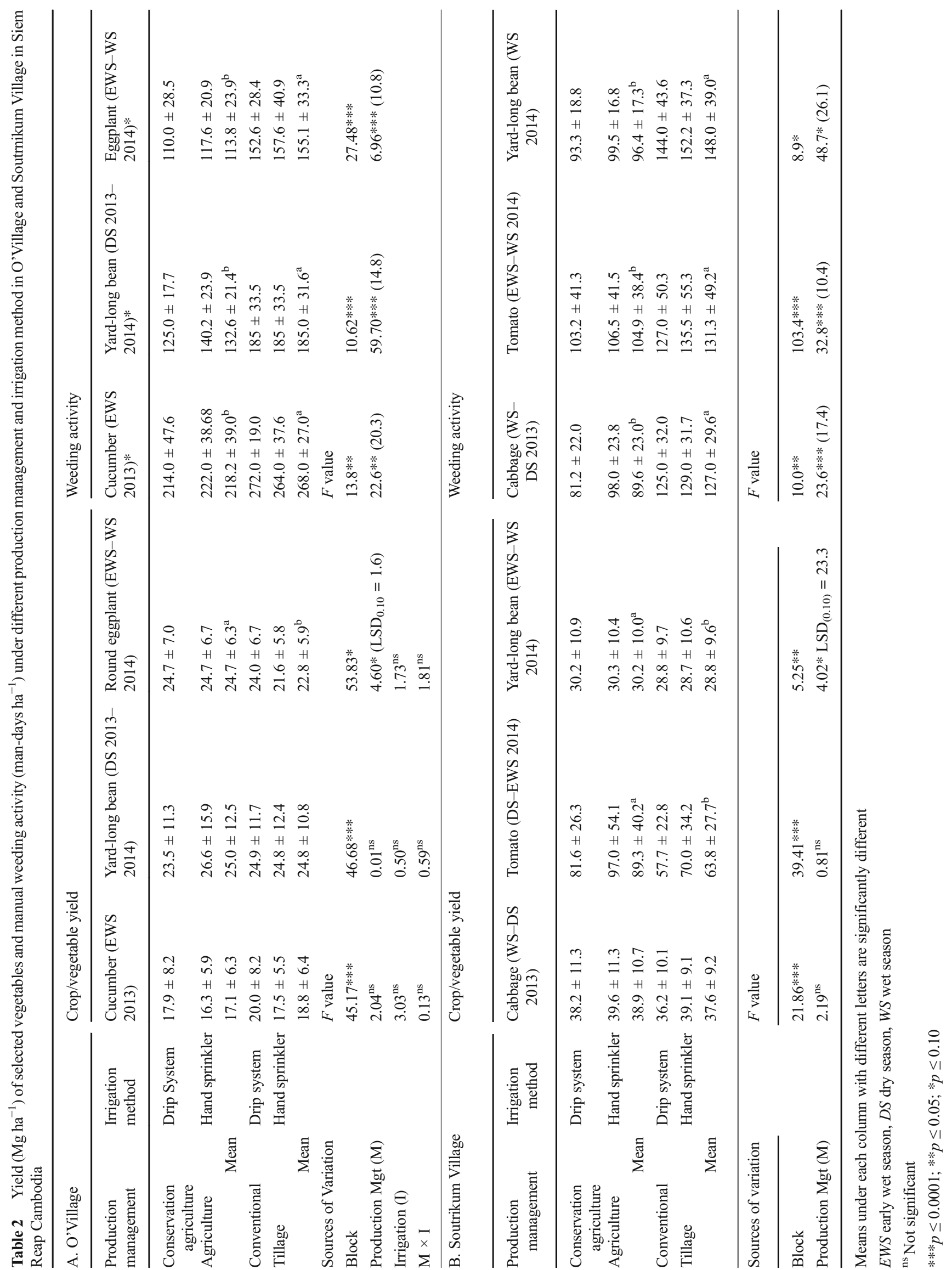


In another village of Soutrnikum, the average yield of cabbage during the WW-DS 2013 season from plots with conservation agriculture $\left(38.9 \pm 10.7 \mathrm{Mg} \mathrm{ha}^{-1}\right)$ was slightly higher than the yield of cabbage $\left(37.6 \pm 9.2 \mathrm{Mg} \mathrm{ha}^{-1}\right)$ from plots under conventional tillage. The yield of both tomato and yard-long bean in Soutrnikum Village was significantly $(p \leq 0.05)$ affected by production management system (Table 2). The average yield of tomato in conventional tilled plots was about $63.8 \pm 27.7 \mathrm{Mg} \mathrm{ha}^{-1}$ compared with the average yield of tomato from plots with conservation agriculture of about $89.3 \pm 40.2 \mathrm{Mg} \mathrm{ha}^{-1}$. The average yield of yard-long bean was significantly increased by about $5 \%$ between conventional tillage $\left(28.8 \pm 9.6 \mathrm{Mg} \mathrm{ha}^{-1}\right)$ and conservation agriculture $\left(30.2 \pm 10.0 \mathrm{Mg} \mathrm{ha}^{-1}\right)$. Yield of tomato and yard-long bean were affected neither by irrigation method nor by the interaction of production management treatment and irrigation method (Table 2).

The yield of selected vegetables in conservation agriculture showed an increasing trend after the second crop. Our results demonstrated significant increase in yield of round eggplant following cucumber and yard-long bean in O'Village (Table 2). Yield of tomato and yard-long bean were likewise increased following cabbage in Soutrnikum Village. This may be due to the improvement in soil fertility from the mineralization of soil organic carbon resulting from crop residues. The soil organic carbon came from the rice straw mulch left on top of the soil and roots from the crops that were left in the ground. Also, the above- and belowground residues of Crotalaria juncea may have added to the soils' organic carbon content and its mineralization may have added other nutrients, especially nitrogen, being a legume. Our observations were consistent with the findings reported by Edralin et al. (2016). They observed that soil organic carbon, soil total nitrogen, and soil respiration for at least in two villages in Siem Reap, Cambodia, were significantly affected by tillage management. After two harvests, addition of residues from mulch, and cover crop production, the average soil organic carbon was observed to be higher in conservation agriculture compared with conventional tillage.

The overall increase in soil organic carbon of conservation agriculture when compared with conventional tillage was associated with the following: (a) keeping the disturbance impact between the mechanical implements and soil to an absolute minimum, (b) using effective crop rotations and association, and (c) leaving crop residues as carbon source on the soil surface. In contrast, tillage tends to engender accelerated oxidative breakdown of organic matter with enhanced release of increased volumes of $\mathrm{CO}_{2}$ to the atmosphere, beyond those from normal soil respiration processes (Kassam et al. 2009).

Higher yields and potentially higher stable incomes can be obtained from conservation agriculture. Kassam et al. (2009) concluded the effect of conservation agriculture to be productive because of improved interactions between the four factors of productivity: (i) physical — better characteristics of porosity for root growth, movement of water, and root-respiration gases; (ii) chemical-raised cation exchange capacity of soils gives better capture, with greater control/release of nutrients; (iii) biological - more organisms, organic matter, and its transformation products; (iv) hydrological - more water available. Additionally, conservation agriculture can reverse the loss of soil organic matter in contrast with conventional tillage, and improve and maintain soil porosity thus prolonging the availability of plant-available soil water in times of drought (Stewart 2007; Derpsch 2008; Mazvimari and Twomlow 2008; Kassam et al. 2009).

The legume cover crop Crotalaria juncea may have increased soil organic carbon and total nitrogen. Field soil respiration rate, based on actual field soil temperature and moisture, indicate a good micro-climate for the growth and proliferation of soil fauna, as well as the release of nutrients from the mineralization of soil organic carbon. Also, lower soil temperature and higher soil water content were observed during the dry season in conservation agriculture compared with conventional tillage. The soil's function of supporting plant growth, habitat for soil microorganisms, and sink for carbon and recycler of nutrients likely improved more in conservation agriculture than in conventional tillage. Results of our study support the overall premise of conservation agriculture. Conservation agriculture is a concept of crop production that aims to save resources and strives to achieve acceptable profits with high and sustained production levels, while at the same time conserving the environment. Boddey et al. (2006) reported that by avoiding tillage, maintaining mulch cover using sequences of different crops and cover crops in multi-year rotations through conservation agriculture can provide both protection to the surface and substrate for the organism beneath, subsequently promoting nitrogen fixing to provide significant proportion of nitrogen.

The effect of irrigation and its interaction with production management were not observed. This may be because the water supplied to the plants for both irrigation treatments was about the same. For example, with drip irrigation during the dry season, water inside the 500-L tanks was emptied halfway into $50-\mathrm{m}^{-2}$ plots in the morning and the other remaining half in the afternoon. The total amount of $1000 \mathrm{~L}$ applied in $100 \mathrm{~m}^{2}$ using the hand sprinkler system was the same. Irrigation by hand sprinkler was done twice daily during the dry season, one irrigation activity in the morning and another in the afternoon. Farmers carried two water cans, containing $10 \mathrm{~L}$ each, to and from their water reservoir about 10 $15 \mathrm{~m}$ away for a total of 25 trips to water $100 \mathrm{~m}^{-2}$. Since farmers did this twice a day, the total water supplied by sprinkler was also about $1000 \mathrm{~L}$ applied to $100-\mathrm{m}^{-2}$ plots.

Labor savings are, however, seen when farmers use a motorized water pump to add water to the tanks. Labor from walking a total distance of about 1 to $1.5 \mathrm{~km}$ with $20-\mathrm{kg}$ 
shoulder load was saved. In addition, the time it took to do manual hauling and delivery of water to plants in $50-\mathrm{m}^{-2}$ plots was reduced by $40 \mathrm{~min}$ using drip irrigation. While the advantage of drip irrigation was looked into, it would also be worth noting that conservation agriculture protected the irrigation tapes from being exposed to solar radiation. Where they were exposed, such as in plots with conventional tillage, irrigation drip tapes could be warped, resulting for more time for farmers to straighten compared with conservation agriculture where they were covered with mulch. In addition, during the succeeding crops' establishment, the already scorched irrigation drip tapes became brittle, cracked, and needed to be replaced.

A low-cost drip irrigation system $\left(\$ 127.00\right.$ per $\left.100 \mathrm{~m}^{-2}\right)$ that was incorporated into our experiment resulted in potential labor reductions and yield improvement especially during the dry season (6 months, November to April) and during the early wet season (EWS) with an erratic rainfall pattern (Seng et al. 2005). Reduction of plant diseases as a result of watering directly to the soil's roots was also observed in our study. Additional advantages of drip irrigation, among others, would include precise application of water onto plant roots which could result to reduced water and energy cost, less disease pressure because the leaves remain dry, and better weed control while soil erosion can be avoided (Palada et al. 2011). Further, the presence of mulch layers in conservation agriculture can reduce soil temperature, resulting in high accumulation of soil organic carbon (Thiombano and Meshack 2009; Silici 2010).

Lastly, it is quite important to recognize that the improvements of crop yields seen and obtained from our study are driven by essential features and processes happening at the micro-scale in the soil itself. Our results were consistent with the findings of Kassam et al. (2009). They reported that widespread adoption of conservation agriculture was capable of producing large savings in machinery and energy use, rise in soil organic matter content, and biotic activity, less erosion, increased crop-water availability, and thus resilience to drought in weather associated with climate change. It will cut production cost, leading to more reliable harvests, and reduce risks especially for small landholders (FAO 2008).

The potential increase of soil organic carbon in plots with conservation agriculture may be due to the addition of about $15 \mathrm{Mg} \mathrm{ha}^{-1}$ rice mulch in two separate occasions before planting time. In addition, the planting of Crotalaria juncea in between rows of long bean and cabbages during the second production prior to their harvesting time may also have added to the soil organic carbon of the soil. The root residues of previous crops, which were retained in conservation agriculture and uprooted in convention tillage, may have had added greater soil organic carbon in conservation agriculture compared with the system with convention tillage. As one of the most widely grown green manure crops, throughout the tropics, sunn hemp is often grown in rotation with several different crop species (Kundu 1964; Srivastasa and Pandit 1968; Rotar and Joy 1983). It produced high organic matter yields, was able to fix nitrogen, and could reduce the build-up of root-knot nematode populations (Breitenbach 1958; Dempsey 1975). Like any other field crops, sunn hemp is reported to be susceptible to attack from fungal pathogens (Streets and Bloss 1973; Cook and Hickman 1990). Control of this pathogen can be achieved through cultural practices and crop rotations which are the central focus in conservation agriculture.

Our results were supported by the early findings of Stevenson (1982) and Paustian et al. (1997). Al-Sheikh et al. (2005) showed that when a cover crop residue is incorporated or a cover crop with deep root system is grown and incorporated in sandy soils, soil organic carbon sequestration can increase. When this happens, residues decay more rapidly for three main reasons: first, for the direct contact with soilborne decomposing organisms; second, for the generally favorable soil conditions for microbial decomposition in terms of moisture and temperature; and third, for the favorable conditions for microbial activity resulting from optimum soil aeration (Magdoff and Weil 2004).

\subsection{Weeding activity}

Weeding activities in two villages O’Village and Soutrnikum Village located in Siem Reap, Cambodia, varied significantly with production management, but not with different irrigation method (Table 2). Weeding activity was significantly $(p \leq 0.0001)$ reduced in plots with conservation agriculture across the two villages. In O'Village, weeding activity in plots with cucumber was reduced from $268.0 \pm 27.0$ to $218.2 \pm 39$ man-day $\mathrm{ha}^{-1}$ between conventional tillage and conservation agriculture. In yard-long bean, weeding activity was reduced from $185.0 \pm 31.6$ to $132.6 \pm 21.4$ man-day ha $^{-1}$. Weeding activity in plots with round eggplant was also reduced because of conservation agriculture (113.8 \pm 23.9 manday $\mathrm{ha}^{-1}$ ) when compared with conventional tillage $\left(155.1 \pm 33.3\right.$ man-day ha $\left.^{-1}\right)$.

In Soutrnikum Village, weeding activity in plots with cabbage was significantly reduced from $127.0 \pm 29.6$ manday $\mathrm{ha}^{-1}$ for conventional tillage to $89.6 \pm 23.0$ manday $\mathrm{ha}^{-1}$ for conservation agriculture. Between conventional tillage and conservation agriculture, weeding activity (manday $\mathrm{ha}^{-1}$ ) was reduced by about $20 \%$ in plots planted with tomato. Similarly, weeding activity in plots with yard-long bean was reduced from $148.0 \pm 39.0$ to $96.4 \pm 17.3$ manday $\mathrm{ha}^{-1}$ between production management of conventional tillage and conservation agriculture, respectively (Table 2).

Reduction of weeding time per hectare was significantly greater in conservation agriculture than in conventional tillage in all production seasons and production times (Table 2). This may be attributed to the weed suppression as a result of mulch. 
The effect of different irrigation methods in reducing weed activities was not seen to be significantly different from each other in terms of weeding, suggesting drip irrigation system and hand sprinkler may have had the same level of effect on weed growth suppression or otherwise. The importance of weed control is among the most emphasized for the success of no-till vegetables (Morse 1999; Mulvaney et al. 2011). Weeds compete for nutrients, water, and sunlight and may provide adverse allelopathic effects to vegetables leading to low yields (Giller et al. 2009).

As shown by the results of our study on reducing weeding activities across the two villages, the use of cover crops in conservation agriculture can suppress weeds via rapid growth, providing a thick ground cover (Blackshaw et al. 2007). A cover crop if planted correctly and managed well in conservation agriculture system can give nearly $100 \%$ weed control while it is growing, and substantial weed management benefits in subsequent vegetables (Blackshaw et al. 2007; Mariki and Owenya 2007; Gan et al. 2008). However, a cover crop if poorly managed could become problematic in the adoption of conservation agriculture. A vigorous, fast-growing cover competes strongly with weeds for space, light, nutrients, and moisture and can thereby reduce weed growth by $80-100 \%$ for the duration of the cover crop's life cycle.

Vigorous growth of cover crops with extensive root systems in our plots with conservation agriculture can provide some added measures of weed control. Plant root exudate and plant-microbe interactions can also influence certain microorganism and/or classes of microorganisms in the soil as a whole, with subsequent effects on other plants (Haramoto and Gallandt 2004). The mulch effect in conservation agriculture is another benefit in hindering weed growth, hence reducing weeding activity. Soil surface mulch can continue to suppress weed growth. In contrast to conventional tillage, the organic mulch in plots with conservation agriculture can reduce the number of weed seeds and germination rate of weeds. In addition, organic mulch provides habitat for ground beetles and other predators of weed seeds, as well as microorganisms that can attack and kill weed seedlings (Haramoto and Gallandt 2004).

\section{Conclusion}

Our results support the overall premises of conservation agriculture. Results have shown that in smallholder commercial household farms, adoption of conservation agriculture had profitable production management system, which could save natural resources, improve yield, and reduce labor. Important results of our study are summarized as follows:

- The yield of agricultural crops was similar in conservation agriculture and conventional tillage during the establishment phase. However, crop yields were significantly improved in conservation agriculture compared with conventional tillage, starting on the third cropping season;

- The low-cost irrigation (drip irrigation system) did not show any significant effect on crop yield, but labor reductions in the field with respect to weeding activities were observed by as much as $65 \%$; and

- The manual weeding in all cropping seasons was significantly reduced by about $30 \%$ in conservation agriculture, which can be attributed to existing cover crops and surface mulch.

Overall, yield improvement and reduction of labor costs due to adoption of conservation agriculture in our study can be attributed to three-component production systems namely (i) minimum soil disturbance, (ii) continuous mulch, and (iii) diverse species in space and time. Although the applicability of this research is limited to intensive commercial household production, where management is optimum, conservation agriculture had shown crop yield improvement compared with conventional tillage in the sandy soils of Cambodia. Additional studies are encouraged to further test the system for a longer period of time, with repeated cropping sequences.

Acknowledgements This research was made possible through the generous support of the American people provided to the Feed the Future Horticulture, Sustainable Agriculture and Natural Resources Management, and Sustainable Intensification Innovation Labs through the United States Agency for International Development (USAID). The participation of the women household farmers in Siem Reap, Cambodia are greatly appreciated. The partnership with the Coastal Plains Soil, Water and Plant Research Center, Agricultural Research Service of the United States Department of Agriculture (USDA) is greatly acknowledged. The contents are the responsibility of the authors and do not necessarily reflect the views of the USAID or the United States government.

\section{References}

Al-Sheikh A, Delgado JA, Barbarick K, Sparks R, Dillon M, Qian Y (2005) Effects of potato-grain rotations on soil erosion, carbon dynamics and properties of rangeland sandy soils. J Soil Tillage Res 81:227-238. https://doi.org/10.1016/j.still.2004.09.010

Blackshaw RE, Harker KN, O'Donovan JT, Beckie HJ, Smith EG (2007) Ongoing development of integrated weed management systems on the Canadian prairies. Weed Sci 56:146-150. https://doi.org/10. 1614/WS-07-038.1

Boddey RM, Bruno JRA, Irquiaga S (2006) Leguminous biological nitrogen fixation in sustainable tropical ecosystems. In: Upholf N, Ball AS, Fernandez E, Herren H, Husson O, Laing M, Palm C, Pretty J, Sanchez P, Sanginga N, Thies J (eds) Biological approaches to sustainable soil systems. CRC Press, Taylor \& Francis Group, Boca Raton, pp 401-408. https://doi.org/10.1201/9781420017113.ch27

Breitenbach CA (1958) Land management practices for kenaf production. p. 97-101. In: Proc. World Conf. on Kenaf. ICA, Havana, Cuba

Cook CG, Hickman MV (1990) Response of kenaf and sunn crotolaria to Phytomatotrichopsis omnivora. Guayulero 12:4-9

Dempsey JM (1975) Fiber crops. The University Press of Florida, Gainesville, p 10 
Derpsch R (2008) No-tillage and conservation agriculture: a progress report. In: T. Goddard et al., editors, No-till farming systems. World Association of Soil and Water Conservation, Bangkok 3, p. 7-39

Edralin DI, Sigua GC, Reyes MR (2016) Dynamics of soil carbon, nitrogen and soil respiration in farmer's field with conservation agriculture, Siem Reap, Cambodia. Int J Plant Soil Sci 11(1):1-13. https:// doi.org/10.9734/IJPSS/2016/25339

Ella VB, Reyes MR, Yoder R (2008) Effect of hydraulic head and slope on water distribution uniformity of a low-cost drip irrigation system. SANREM CRSP OIRED Working Paper No. 01-08

FAO (2001) Conservation agriculture, case studies in Latin America and Africa. FAO Soils Bulletin 78. FAO, Rome, Italy. http://www.fao. org/docrep/003/y1730e/y1730e00.HTM (accessed 1 Nov. 2011)

FAO (2006) Report on plant breeding and biotechnology capacity survey Thailand. http://apps3.fao.org/wiews/docs/Thailand\%20Full\% 20Report.pdf. (accessed 22 July, 2017)

FAO (2008) Investing in sustainable crop intensification: a farmer discovery process going to scale in Barkina Faso. Integrated Crop Management. Volume 7. Rome. ISBN 978-92-5-106323-1

FAO (2011) Save and grow, a policy maker's guide to the sustainable intensification of smallholder crop production. FAO, Rome. http:// www.fao.org/docrep/014/i2215e/i2215e.pdf Accessed 1 Nov 2011

Faroooq M, Flower KC, Jabran K, Wahid A, Siddique KHM (2011) Crop yield and weed management in rainfed conservation agriculture. Soil Tillage Res 117:172-183. https://doi.org/10.1016/j.still.2011.10.001

Gan Y, Harker KN, McConkey B, Suleimanov M (2008) Moving towards no-till practices in Northern Euresia. In: Goddard T, Zoebisch MA, GanYT EW, Watson A, Sombatpanit S (eds) No-till farming systems. Special Publication No. 3. World Association of Soil and Water Conservation, Bangkok, pp 179-195

Giller KE, Witter E, Corbeels M, Tittonel P (2009) Conservation agriculture and smallholder farming in Africa: the heretics' view. Field Crops Res 114:22-34. https://doi.org/10.1016/j.fcr.2009.06.017

Govaerts B, Verhulst N, Castellanos-Navarrete A, Sayre KD, Dixon J, Dendooven L (2009) Conservation agriculture and soil carbon sequestration: between myth and farmer reality. Crit Rev Plant Sci 28(3):97-122. https://doi.org/10.1080/07352680902776358

Haramoto ER, Gallandt ER (2004) Brassica cover cropping for weed management: a review. Renewable Agric Food Syst 19:187-198. https://doi.org/10.1079/RAFS200490

Hobbs PR (2007) Conservation agriculture: what is it and why is it important for future sustainable food production? J Agric Sci 145:127137. https://doi.org/10.1017/S0021859607006892

Hobbs PR, Sayre K, Gupta R (2008) The role of conservation agriculture in sustainable agriculture. Philos Trans R Soc B 363:543-555. https://doi.org/10.1098/rstb.2007.2169

Kassam A, Friedrich T, Shaxson F, Pretty J (2009) The spread of conservation agriculture: justification, sustainability and uptake. Int J Agric Sustain 7(4):292-300. https://doi.org/10.3763/ijas.2009.0477

Kundu BC (1964) Sunn-hemp in India. Proc Soil Crop Soc Florida 24: 396-404

Lal R (2008) Promise and limitations of soils to minimize climate change. J Soil Water Conserv 63(4):113A-118A. https://doi.org/10.2489/ jswc.63.4.113A

Linden DR, Clapp CE, Dowdy RH (2000) Long-term corn grain and stover yields as a function of tillage and residue removal in east central Minnesota. Soil Tillage Res 56:167-174. https://doi.org/10. 1016/S0167-1987(00)00139-2

Magdoff F, Weil RR (2004) Soil organic management strategies. In: Magdoff F, Weil RR (eds) Soil organic matter in sustainable agriculture. CRC Press, New York, pp 45-65

Mariki WL, Owenya MZ (2007) Weed management In conservation agriculture for sustainable crop production. Proceeding of the International Workshop on Conservation Agriculture for Sustainable Land Management to Improve the Livelihood of People in Dry Areas. pp. 49-56. Damascus, Syria
Mazvimari K, Twomlow S (2008) Conservation farming for agricultural relief and development in Zimbabwe. In: Goddard T, Zoebisch MA, Gan YT, Ellis W, Watson A, Sombatpanit S (eds) No-till farming systems. Special Publication No. 3. World Association of Soil and Water Conservation, Bangkok, pp 169-175

Morse RD (1999) No-till vegetable production - its time is now. HortTechnology 3:373-379

Mulvaney MJ, Price AJ, Wood CW (2011) Cover crop residue and organic mulches provide weed control during limited-input no-till collard production. J Sustain Agric 35(3):312-328. https://doi.org/10. 1080/10440046.2011.554315

Palada M, Bhattarai S, Wu DL, Roberts M, Bhattarai M, Kimsan R, Midmore D (2011) More crop per drop: using simple drip irrigation systems for small-scale vegetable production. AVRDC Publication No. 09-723. AVRDC-The World Vegetable Center, Shanhua, Taiwan. 83 pp.

Paustian K, Collins HP, Paul EA (1997) Management controls on soil carbon. In: Paul EA, Paustian K, Elliot ET, Cole CV (eds) Soil organic matter in temperate agroecosystems: long term experiments in North America. CRC Press, Boca Raton, pp 15-49

Rotar PP, Joy RJ (1983) 'Tropic Sun' sunn hemp, Crotalaria juncea L. Univ. of Hawaii, College of Tropical Agr. And Human Resources, Institute of Tropical Agr. and Human Resources Research Extension Series 36

Seng V, Bell RW, White PF, Schoknecht N, Hin S, Vance W (2005) Sandy soils of Cambodia. FAO, Rome, Italy. http://www.fao.org/ docrep/010/ag125e/AG125E07.htm (accessed 1 Nov. 2011)

Silici L (2010) Conservation agriculture and sustainable crop intensification in Lesotho, vol 61. Food and Agriculture Organization of the United Nations, Rome

Soil Quality Institute Staff (1998) Soil quality test kit guide. USDA Washington, DC. United States Census Bureau 2011. International Database. Available: http://www.census.gov/ population/ international/data/ibd/worldpopgraph.php

Srivastasa SC, Pandit SN (1968) Relative role of sunn hemp for tops and roots in contributing to the green-manuring benefits of sugarcane. Indian J Agr Sci 38:338-342

Stevenson FJ (1982) Origin and distribution of nitrogen in soils. In: Stevenson FJ (ed) Nitrogen in agricultural soils. Agronomy No. 22. 1982. Agronomy Society of America, Madison, pp 1-42. https://doi.org/10.2134/agronmonogr49.c1

Stewart BA (2007) Water conservation and water use efficiency in drylands. Proceeding of the International Workshop on Conservation Agriculture for Sustainable Land Management to Improve the Livelihood of People in Dry Areas. pp. 57-66. Damascus, Syria

Streets RB, Bloss HE (1973) Phymatotrichum root rot. Monogr. 8. The American Phytopathological Society, St. Paul, p 45

Thierfelder C, Matemba-Mutasa R, Rusinamhodzi L (2015) Yield response of maize (Zea mays L.) to conservation agriculture cropping system in Southern Africa. Soil Tillage Res 146:230-242. https:// doi.org/10.1016/j.still.2014.10.015

Thiombano L, Meshack M (2009) Scaling-up conservation agriculture in Africa: strategy and approaches, Vol. 31. Food and Agriculture Organization of the United Nations, Sub-Regional Office for Eastern Africa, Addis Ababa

Vanlauwe B, Wendt J, Giller KE, Corbeels M, Gerard B, Nolte C (2014) A fourth principle is required to define conservation agriculture in sub-Saharan Africa: the appropriate use of fertilizer to enhance crop productivity. Field Crops Res 155:10-13. https://doi.org/10.1016/j. fcr.2013.10.002

World Bank Group (2015) Climate change knowledge portal. World Bank, Washington, DC. http://sdwebx.worldbank.org/climateportal/index. $\mathrm{cfm}$ ? page $=$ country_historical_climate $\&$ ThisRegion $=$ Asia\&ThisCCode $=$ KHM Accessed 30 April 2015 